Єрешко Ю. О. 11: : :RC1010:0000-0002-9161-8820], к.е.н., доцент

${ }^{1}$ Національний технічний університет України «Київський політехнічний інститут імені Ігоря Сікорського»

\title{
ФОРМАЛІЗАЦІЯ ІНТЕЛЕКТУАЛЬНОЇ ТЕОРІЇ ВАРТОСТІ
}

У статті здійснюється спроба формалізації нової інтелектуальної теорії вартості шляхом інтерпретації трудової теорії Маркса 3 позиції розбиття додаткової вартості за джерелами їі створення, а саме: трудовим капіталом (працею) та інтелектуальним капіталом. При цьому впроваджено фактори ваги експлуатації цих джерел в процесі створення вартості. Запропоновано діалектичне декомпонування і синтез категорій «вартість», «цінність» та «ціна» на основі методології причинності явищ 3 точки зору їх сприйняття суб'єктами створення вартості у виробництві та обміні. Визначено, що вартість є об'єктивною цінністю товару, загальним для обох, протиставних 3 точки зору секторів ринку, систем її сприйняття, об'єктивною основою формування суб'єктивної цінності 3 позицій покупця і продавця (виробника) (або їх сукупностей), конфлікт яких вирішується на ринку взаємодією репрезентованих відповідно попиту і пропозиції, а результатом вирішення цього конфлікту стає домовленість суб'єктів обміну про уніфіковану (десуб'єктивну) цінність - ринкову ціну товару. Проведене дослідження дозволило гіпотетично формалізувати інтелектуальну теорію вартості. Водночас подальших досліджень потребує розробка методичного інструментарію, що дозволить визначити границі фактору інтелектуального капіталу у новоствореній вартості.

Ключові слова: вартість; цінність; ціна; норма додаткової вартості; норма прибутку; інтелектуальний капітал; інтелектуальна теорія вартості.

Постановка проблеми. Сучасний щабель розвитку продуктивних сил в процесі трансформаційних постіндустріальних змін, впровадження «нових комбінацій використання ресурсів» [1] спонукає до чергового переосмислення структури вартості виходячи з нового, інноваційного, характеру розвитку суспільства та економіки.

Попередньо у [2] нами обґрунтовано потребу і методологічні засади формулювання нової теорії вартості, виходячи із особливостей і закономірностей господарювання економічних агентів в умовах інтелектуальної і технологічної трансформації в 
переході до нового техніко-технологічного укладу, а також, ретроспекцію теорій вартості та концепцій виробничих факторів. Еволюційна протиставність наведених теорій, на наш погляд, $€$ сумнівною, адже розвиток поглядів на фактори і структуру вартості відбувається в діалектичній єдності і, відтак, логічній послідовності. 3 рештою, саме така послідовність пізнання економічної сутності категорії «вартість товару» дає нам підставу стверджувати про відсутність, вірніше, недослідженість такого чільного елемента у структурі вартості, як знання.

«Усі товари, - пише Маркс, - можуть бути зведені до праці, як до того, що в них єдине» [3], перефразовуючи А. Сміта: «Вони <товари> містять вартість відомої кількості праці, яку ми обмінюємо на те, що, на наш погляд, містить в собі вартість аналогічної кількості праці» [4]. Така теза більш ніж справедлива для рівня суспільноекономічного розвитку часів Маркса та Сміта, проте сьогодні праця як фактор виробництва поступово зникає у деяких сферах і галузях економіки внаслідок активної автоматизації і роботизації виробництва. Однак, людина як фактор виробництва залишається у вигляді знань, знань особистісних і уречевлених у інших продуктивних факторах.

Постановка завдання. Таким чином, можна висловити гіпотезу про те, що сьогодні таким об'єднуючим фактором для всіх товарів $€$ знання та інші прояви людської свідомості - інтелектуальна складова вартості, оскільки, саме вони, на відміну від праці, присутні у всіх сферах і галузях суспільного виробництва, незалежно від рівня розвитку конкретних засобів виробництва. На підтримку нашої думки можна навести цитату Т. Хоббса, який ще у XIX ст. називав науку «матір'ю мистецтв»: «Мистецтва, що мають значення для суспільства, як, наприклад, фортифікація, створення машин та інших засобів ... являють собою силу... і, хоча істинною матір'ю їх $€$ наука ... все ж, оскільки виробляються вони рукою ремісника, вони розглядаються як його творіння» [5]. До речі, в епоху античності, «матір'ю та годувальницею всіх мистецтв» Ксенофонт вважав землеробство: «Коли процвітає землеробство, процвітають і інші мистецтва» [6].

Відповідно, постає проблема формалізації нової теорії вартості, що дозволить наочне уявлення про процес іï створення, а відтак, модернізацію управління її компонентами та раціоналізацію використання вартісноформуючих продуктивних сил.

Основні результати дослідження. Вважаємо, що на сучасному етапі соціального та економічного розвитку, саме наука і знання, а 
точніше, продуктивна частина знань у вигляді інтелектуального капіталу, $\epsilon$ джерелом вартості товару в умовах постіндустріальної (неоіндустріальної) економічної системи. Крім того, сформульована нами у [2] «інтелектуальна теорія вартості» не $\epsilon$ запереченням синтетичної, а радше, ії логічним продовженням, оскільки, інтелектуальна складова присутня у обидвох елементах вартості: об'єктивному - в якості визначального чинника науково-технічного розвитку засобів виробництва, і суб'єктивному - впливаючи на формування споживчої поведінки шляхом використання іміджу, брендів, репутації, компетенції співробітників, піару тощо.

Водночас належить розрізняти категорії «цінність» і «вартість»: хоча й ототожнювані Ксенофонтом, Смітом, Петті, Сеєм і деякими маржиналістами, - вони лежать в різних площинах і дістають діалектичного поєднання в процесі товарообміну економічними суб'єктами. Вважаємо вартість об'єктивною цінністю товару, загальним для обох, протиставних з точки зору секторів ринку, систем їі сприйняття. Суб'єктивна цінність же лежить в площині індивідуального сприйняття вартості суб'єктами ії створення i споживання в процесі виробництва та/або обміну. При цьому, суб'єктивна цінність товару, має двоїстий характер, об'єктивною основою якого $є$ двосуб'єктність відносин обміну (рис. 1).

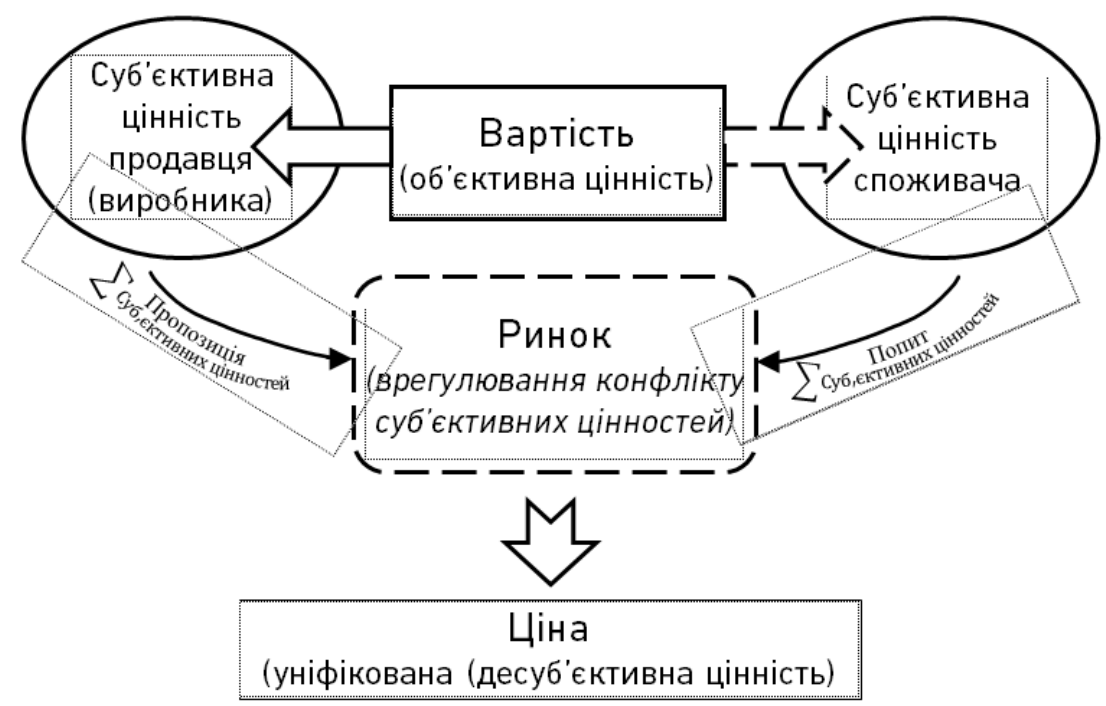

Рис. 1. Вартість, суб'єктивна цінність і ціна товару *Джерело: побудовано автором

Так, з позиції споживача товару вона проявляється як особиста корисність, яка визначається індивідом, виходячи із можливості задоволення його специфічних потреб, вподобань, бюджетних обмежень тощо. Водночас для виробника або продавця, суб'єктивна цінність товару репрезентується можливістю задоволення його 46 
економічних потреб: отриманням доходу, додаткової вартості в процесі його реалізації, окреслених ще Т. Мальтусом: «необхідні умови потрапляння товару на ринок, тобто умови виготовлення, а вірніше відтворення товару на засадах капіталістичного виробництва полягають в тому, що товар або його вартість обмінюється ... на більшу кількість праці, ніж та, що в ньому міститься, адже товар виготовляється для того, щоб отримати прибуток» [7]. Звідси, вартість $€$ об'єктивною основою формування суб'єктивної цінності з позицій покупця і продавця (виробника) (або ї сукупностей), конфлікт яких вирішується на ринку взаємодією репрезентованих відповідно попиту і пропозиції, а результатом вирішення цього конфлікту стає домовленість суб'єктів обміну про уніфіковану (десуб'єктивну) цінність - ринкову ціну товару.

Знанням як компонентним різновидам інтелектуального капіталу, а також, проявам індивідуальної свідомості, властива мультихарактерна природа та системна неоднорідність, вирізняє їх 3-поміж «традиційних» економічних факторів: так, частина знань і проявів людської свідомості не може бути відокремленою від їх носія, або не піддається копіюванню, інші, навпаки, - активно і вільно тиражуються. Таким чином, з одного боку, підприємства не володіють інтелектуальним капіталом повністю - його частина належить робочій силі, покупцям, контрагентам, посередникам тощо, з іншого - зважаючи на сучасні бізнесові тенденції, коефіцієнт експлуатації носіїв інтелектуального капіталу прирівнюється (якщо не перевищує) до коефіцієнта експлуатації робочої сили часів Марксової теорії «додаткової вартості».

Формалізацію інтелектуальної теорії вартості вважаємо раціональним здійснити шляхом інтерпретації трудової Маркса:

$$
W=c+v+m \text {, }
$$

де $W$ - вартість товару; $c$ - постійний капітал, авансований у засоби виробництва, що не генерують в процесі кругообігу додаткової вартості, а переносять свою вартість на вартість готової продукції повністю у вигляді матеріальних витрат, або частинами - у вигляді амортизації; $v$ - змінний капітал, який в процесі виробництва створює нову вартість і авансований на купівлю робочої сили; $m$ додаткова вартість, створена в результаті обороту капіталу.

Економічну структура Марксової теорії вартості можна схематично представити як (рис. 2): 


\begin{tabular}{|c|c|c|}
\hline $\begin{array}{c}\text { Витрати постійного } \\
\text { капіталу, с }\end{array}$ & $\begin{array}{c}\text { Витрати змінного } \\
\text { капіталу, } v\end{array}$ & $\begin{array}{c}\text { Додаткова } \\
\text { вартість, } \mathrm{m}\end{array}$ \\
\hline \multicolumn{2}{|c|}{ Вартість } \\
\hline
\end{tabular}

Рис. 2. Економічна структура вартості за К. Марксом

Джерело: побудовано автором на основі [8]

Для наочнішого уявлення про актуальність Марксової концепції походження прибутку в умовах капіталізму та індустріальної економіки, належить спроектувати Марксове уявлення структури вартості на структуру капіталу Дж. Кларка (рис. 3). 3 точки зору процесу відтворення, витрати виробництва - це частина доходу, що авансується на його продовження, спожитий підприємством капітал компенсується $з$ його доходу, що складається з фондів споживання (витратної частини) та фондів нагромадження (прибутку). А капітал за Дж. Кларком розподіляється на оборотний, що використовується повністю за один виробничий цикл i, відповідно, повністю переносить свою вартість на вартість готової продукції у вигляді матеріальних витрат та заробітної плати, та основний використовується підприємством більше одного виробничого циклу і переносить свою вартість на вартість готової продукції частинами у вигляді амортизації. До речі, структурування капіталу Кларком лежить в основі сучасного економічного і бухгалтерського обліку.

\begin{tabular}{|c|c|c|c|}
\hline \multicolumn{2}{|c|}{ Фонди споживання } & \multicolumn{2}{|c|}{ Новостворена вартість } \\
\hline $\begin{array}{c}\text { Витрати } \\
\text { основного } \\
\text { капіталу } \\
\text { (амортизація) }\end{array}$ & $\begin{array}{c}\text { Витрати } \\
\text { оборотного } \\
\text { капіталу } \\
\text { (матеріальні } \\
\text { витрати) }\end{array}$ & $\begin{array}{c}\text { Витрати на } \\
\text { оплату праці }\end{array}$ & $\begin{array}{l}\text { Валовий } \\
\text { прибуток }\end{array}$ \\
\hline \multicolumn{2}{|c|}{ Витрати постійного капіталу, с } & $\begin{array}{c}\text { Витрати } \\
\text { змінного } \\
\text { капіталу, v } \\
\end{array}$ & $\begin{array}{l}\text { Додаткова } \\
\text { вартість, m }\end{array}$ \\
\hline \multicolumn{3}{|c|}{ Собівартість } & Прибуток \\
\hline \multicolumn{4}{|c|}{ Вартість } \\
\hline
\end{tabular}

Рис. 3. Синтезована економічна структура вартості за К. Марксом та Дж. Кларком

Джерело: побудовано автором на основі [8]; [9]

Така проєкція дозволяє ілюстрацію рікардівського закону оберненості обсягів прибутку капіталіста та оплати праці робітників. 48 
3 огляду на наведену економічну структуру вартості, стає очевидним прагнення переважної більшості підприємців до автоматизації виробництва та зменшення витрат фізичної праці, що $\epsilon$ елементарним методом збільшення частки додаткової вартості, тобто прибутку, у валовому доході підприємства (новоствореній вартості). Дана залежність ґрунтується на трудовій теорії вартості К. Маркса і, безперечно, $€$ найшвидшим і найбільш очевидним способом досягнення зростання прибутковості інтенсивним шляхом [10]. Водночас це очевидне прагнення результує в інтелектуальній і технологічній трансформації продуктивних сил внаслідок ентропії техніки у всі сфери суспільної життєдіяльності, як наслідок, змінюючи структуру виробничих факторів, - перетворює структуру вартості.

Зважаючи на успішну реалізацію цих очевидних прагнень підприємців до мінімізації затрат фізичної праці шляхом заміни живих робітників технікою, автоматизація і роботизація виробничих процесів призводять сьогодні до майже повного витіснення робочої сили в більшості галузей економік розвинених країн світу. Разом 3 тим, людина не зникає з виробничого процесу, оскільки ї̈ знання, уречевлені у новітніх засобах праці, а також, знання, невідокремлювані від людини стають основою вартості в умовах нового техніко-економічного укладу. Таким чином, економічна структура вартості зазнає логічної інтелектуальної трансформації (рис. 4) і їі можна формалізувати як:

$$
\begin{gathered}
W=c+v+\left(a m_{l}+b m_{i}\right), \\
m=\left(a m_{l}+b m_{i}\right), \\
a+b=1,
\end{gathered}
$$

де $W$ - вартість товару; $c$ - постійний капітал, авансований у засоби виробництва, що не генерують в процесі кругообігу додаткової вартості, а переносять свою вартість на вартість готової продукції повністю у вигляді матеріальних витрат, або частинами - у вигляді амортизації; $v$ - змінний капітал, який в процесі виробництва створює нову вартість і авансований на купівлю робочої сили та науково-дослідні і дослідно-конструкторські роботи; додаткова вартість $(m)$, створена в результаті обороту капіталу $\epsilon$ двокомпонентною: $m_{l}$ - результує від робочої сили; $m_{i}$ - генерується інтелектуальним капіталом; при цьому, залежно від наукоємності, сучасності, інноваційності виробництва, галузі економіки, або специфіки - деякі підприємства 3 тих, чи інших причин 
використовують ручну працю, кожна компонента додаткової вартості має параметр $a$ та $b$ - відповідно, що в сумі складають 1.

До прикладу, виробництво новорічних прикрас може відбуватись: 1) автоматизовано, штампуванням 3 пластику 3 орієнтацією на масмаркет - за таких умов можна припустити, що фактор a наближатиметься до 0 значення; 2) частковоавтоматизовано, штампуванням зі скла чи пластику з орієнтацією на масмаркет та нішеву реалізацію (з дизайнерськими зображеннями) фактори $a$ та $b$ залежатимуть від пропорції продукції відповідно обраному сегментуванню, водночас, перший теоретично буде порівняно меншим; 3) ручною працею склодувів та художників 3 нішевою сегментацією - фактори $a$ та $b$ залежатимуть від відповідних вартостей робочої сили та художніх творів; 4) ручною працею склодувів і художників з реалізацією під відомим брендом фактор $a$ буде значно поступатись фактору $b$.

\begin{tabular}{|c|c|c|c|c|}
\hline \multicolumn{2}{|c|}{ Фонди споживання } & \multicolumn{2}{|c|}{ Новостворена вартість } \\
\hline $\begin{array}{c}\text { оботрати } \\
\text { капіталу } \\
\text { (матеріальні } \\
\text { витрати) }\end{array}$ & $\begin{array}{c}\text { Витрати } \\
\text { основного } \\
\text { капіталу } \\
\text { (амортизація) }\end{array}$ & $\begin{array}{c}\text { Витрати } \\
\text { на } \\
\text { оплату } \\
\text { праці }\end{array}$ & $\begin{array}{c}\text { Витрати } \\
\text { на R\&D }\end{array}$ & $\begin{array}{c}\text { Валовий } \\
\text { прббуток }\end{array}$ \\
$\begin{array}{c}\text { Витрати постійного капіталу, с } \\
\text { Собівартість }\end{array}$ & $\begin{array}{c}\text { Витрати змінного } \\
\text { капіталу, } v\end{array}$ & $\begin{array}{c}\text { Додаткова } \\
\text { вартість, } \\
\left(m_{l}+m_{i}\right)\end{array}$ \\
\hline \multicolumn{4}{|c|}{ Вартість } \\
\hline
\end{tabular}

Рис. 4. Сучасна економічна структура вартості Джерело: розроблено автором

Таким чином, границі фактору $b$ залежать від корисної експлуатації інтелектуального фактору вартості, вони можуть відрізнятись для різних галузей економіки, відносно їх виробничої специфічності, а також, для різних підприємств однієї галузі, виходячи із обраної ними бізнес-моделі та рівня інноваційності, а також, інтенсивності інтелектуальної та технологічної трансформації. Разом з тим, значення цього фактору відрізнятиметься і для підприємств одного інноваційного рівня розвитку, залежно від вартості їх бренду та їх репутації, обраної ними цільової аудиторії і збутової політики тощо.

При цьому, переосмислення і реструктуризації потребує, також 
зміст і структура концепту «змінний капітал», виходячи із того, що робоча сила як вартісностворюючий фактор дедалі більше поступається інтелектуальному капіталу. Тому, вважаємо логічним включення витрат, пов'язаних з інтелектуальною та технологічною трансформацією продуктивних сил і виробничих процесів до авансів у змінний капітал, оскільки вони $є$ щонайменше частиною (почасти більшою) вартості, що створює нову вартість в процесі кругообігу.

Таке переосмислення дозволить розрахунок коефіцієнту «експлуатації» інтелектуального капіталу приведенням відомої формули норми додаткової вартості:

$$
\begin{gathered}
m^{\prime}=\frac{m}{v}, \\
m^{\prime}=m_{l}^{\prime}+m_{i}^{\prime}, \\
m_{l}^{\prime}=\frac{m_{l}}{v_{l}} \text { (7) та } m_{i}^{\prime}=\frac{m_{i}}{v_{i}},
\end{gathered}
$$

де $m^{\prime}$ - норма додаткової вартості; що розкладається на компоненти: $m_{l}^{\prime}$ та $m_{i}^{\prime}$ - норми додаткової вартості, створені робочою силою та інтелектуальним капіталом відповідно; $v_{l}$ та $v_{i}$ - аванси на робочу силу та інтелектуальний капітал відповідно.

Виходячи з того, що відношення додаткової вартості $m$ до суми авансів капіталу $K$ запропоновано Марксом в якості визначення норми прибутку $p^{\prime}$, можна припустити, що норма прибутку від використання інтелектуального капіталу вираховуватиметься наступним чином:

$$
p_{i}^{\prime}=m_{i}^{\prime} \frac{v_{i}}{K}
$$

або пропорцією:

$$
p_{i}^{\prime}: m_{i}^{\prime}=v_{i}: K,
$$

де $p_{i}^{\prime}$ - норма прибутку, генерованого інтелектуальним капіталом.

Висновки. Проведене дослідження дозволило гіпотетично формалізувати інтелектуальну теорію вартості. Проблема аналізу економічного ефекту від використання інтелектуального капіталу випливає із проблеми його оцінки. Сьогодні, на жаль, не існує єдиного підходу, що здатен врахувати особливості економічної сутності інтелектуального капіталу і його специфічну мультихарактерну природу. Так, оцінці (разом з тим, доволі часто спірній), безумовно, піддається частина, уречевлена у вигляді інновацій та нематеріальних активів, водночас, особливої складності 
набуває оцінка частини особистісної - потенціалу до генерації людиною знань і потенціалу до перетворення цих знань у інновації, інтелектуальну власність тощо.

Разом з тим, подальших досліджень потребує формалізація інтелектуальної теорії вартості в розрізі розробки методичного інструментарію, що дозволить визначення границь фактору інтелектуального капіталу у новоствореній вартості.

1. Schumpeter J. The Theory of Economic Development. Cambridge; Harvard, 1934. 2. Єрешко Ю. О. Економічна теорія інтелектуального капіталу: інтелектуальна теорія вартості. Економіка і управління. 2016. № 4. С. 5-9. 3. Маркс К., Энгельс Ф. Критика политической экономии : сочинения. 2-е изд. М., 1968. Т. 46. Ч. І. С. 256301. 4. Smith, Adam. An Inquiry into the Nature and Causes of the Wealth of Nations. 1776. Book 2. 5. Hobbes, T., \& Missner, M. (2016). Thomas Hobbes: Leviathan (Longman Library of Primary Sources in Philosophy). Routledge. 6. Johnson, D. M. (2021). Xenophon's Socratic Works: The Other Socrates. 7. Malthus, T. R. (1827). Definitions in political economy. Online Library of Liberty. 8. Marx, K. (2007). Capital: A critique of political economy. Duke University Press. 9. Clark, J. B. (1888). Capital and its Earnings. American economic association. Vol. 3, No. 2. 10. Єрешко Ю. О. Вибір амортизаційної політики 3 точки зору управління конкурентоспроможністю інвестиційного проекту. Формування ринкових відносин в Україні. 2013. № 9. С. 181-183.

\section{REFERENCES:}

1. Schumpeter J. The Theory of Economic Development. Cambridge; Harvard, 1934. 2. Yereshko Yu. O. Ekonomichna teoriia intelektualnoho kapitalu: intelektualna teoriia vartosti. Ekonomika i upravlinnia. 2016. № 4. S. 5-9. 3. Marks K., Engels F. Kritika politicheskoy ekonomii : sochineniya. 2-e izd. M., 1968. T. 46. CH. I. S. 256-301. 4. Smith, Adam. An Inquiry into the Nature and Causes of the Wealth of Nations. 1776. Book 2. 5. Hobbes, T., \& Missner, M. (2016). Thomas Hobbes: Leviathan (Longman Library of Primary Sources in Philosophy). Routledge. 6. Johnson, D. M. (2021). Xenophon's Socratic Works: The Other Socrates. 7. Malthus, T. R. (1827). Definitions in political economy. Online Library of Liberty. 8. Marx, K. (2007). Capital: A critique of political economy. Duke University Press. 9. Clark, J. B. (1888). Capital and its Earnings. American economic association. Vol. 3, No. 2. 10. Yereshko Yu. O. Vybir amortyzatsiinoi polityky $\mathrm{z}$ tochky zoru upravlinnia konkurentospromozhnistiu investytsiinoho proektu. Formuvannia rynkovykh vidnosyn v Ukraini. 2013. № 9. S. 181183. 
Yereshko Y. O. [1; ORCID ID: 0000-0002-9161-8820],

\section{FORMALIZATION OF THE INTELLECTUAL THEORY OF VALUE}

Current research is an attempt to formalize a new intellectual theory of value by interpreting Marx's labour theory of surplus value from the position of breaking down the additional value by sources of its creation, namely: labour capital and intellectual capital. For this purpose, the factors of these sources exploitation in the value creating process were introduced. A dialectical synthesis and decomposition of categories "value", "worth" and "price" was proposed, based on the methodology of phenomena causality in terms of their perception by the subjects of the value creation in the processes of production and exchange. It was determined that the value is an objective worth of the product and is general for both systems of its perception, which are contrast from the point of view of the market sectors. Subjective worth lies but in the plane of individual perception of value by the subjects of its creation and consumption in the process of production and I or exchange. At the same time, the subjective worth of the goods has a dual nature, the objective basis of which is the two-sided essence of exchange: from the position of the goods consumer it manifests itself as a personal utility, which is determined by the individual, based on the possibility of satisfying their specific needs, preferences, budget restraints, etc; for the manufacturer or seller, the subjective worth of the goods is represented by the possibility to satisfy their economic needs: obtaining income, additional value in the process of its implementation. It was substantiated that, the value is an objective basis for the subjective worth formation from the buyer and seller's (manufacturer) positions (or their plurality), the conflict of which is solved in the market by the interaction of represented accordingly demand and supply, and the result of solving this conflict becomes an arrangement of those subjects of exchange about the unified (de-subjective) worth (value) - the market. Given the proposed economic structure of value, apparent becomes the desire of the vast majority of entrepreneurs for automation of production and thus reduction of physical labour costs, which is an elementary method of increasing the share of additional value, that is, profits, in the gross income of the enterprise (newly created value). At the same time, this obvious desire results in the intellectual and technological transformation of productive forces due to entropy of technology in all spheres of social life and this consequential change in the structure of production factors transforms in turn the structure of value. The conducted research allowed to formalize hypothetically the intellectual theory of value. At the same time, further research is required to develop the methodological 
tools, which will allow to define the intellectual capital factor limits $i$ in the newly created value.

Keywords: value; worth; price; additional value rate; profit rate; intellectual capital; intellectual theory of value.

Ерешко Ю. А. [1; ORCID ID: 0000-0002-9161-8820], к.э.н., доцент

${ }^{1}$ Национальный технический университет Украины «Киевский политехнический институт имени Игоря Сикорского»

\section{ФОРМАЛИЗАЦИЯ ИНТЕЛЛЕКТУАЛЬНОЙ ТЕОРИИ СТОИМОСТИ}

В статье осуществляется попытка формализации новой интеллектуальной теории стоимости путем интерпретации трудовой теории Маркса с позиции разбивки прибавочной стоимости по источникам ее создания, а именно: трудового капитала (труда) и интеллектуального капитала. При этом введены факторы эксплуатации этих источников в процессе создания стоимости. Произведена диалектическая декомпозиция и синтез категорий «стоимость», «ценность» и «цена» на основе методологии причинности явлений с точки зрения их восприятия субъектами создания стоимости В производстве и обмене. Определено, что стоимость является объективной ценностью товара, общим для обоих, противопоставленных с точки зрения секторов рынка, систем ее восприятия. Субъективная ценность же лежит в плоскости индивидуального восприятия стоимости субъектами ее создания и потребления в процессе производства и / или обмена. При этом, субъективная ценность товара, имеет двойственный характер, объективной основой которого является двосубъектность отношений обмена: с позиции потребителя товара она проявляется как личная полезность, определяется индивидом, исходя из возможности удовлетворения его специфических потребностей, предпочтений, бюджетных ограничений и тому подобное; для производителя или продавца, субъективная ценность товара представляется возможностью удовлетворения его экономических потребностей: получением дохода, дополнительной стоимости в процессе его реализации. Обосновано, что стоимость является объективной основой формирования субъективной ценности с позиций покупателя и продавца (производителя) (или их совокупностей), конфликт которых решается на рынке взаимодействием соответствующих спроса и предложения, а результатом решения этого конфликта становится договоренность субъектов обмена о унифицированную (десубъективную) ценность - рыночную цену товара. Учитывая приведенную экономическую структуру стоимости, становится очевидным стремление подавляющего большинства предпринимателей 
к автоматизации производства и уменьшению затрат физического труда, что является элементарным методом увеличения доли прибавочной стоимости, то есть прибыли в валовом доходе предприятия (новой стоимости). В то же время это очевидное стремление приводит к интеллектуальной и технологической трансформации производительных сил в результате энтропии техники во все сферы общественной жизнедеятельности, как следствие, изменяя структуру производственных факторов, - изменяет структуру стоимости. Проведенное исследование позволило гипотетически формализовать интеллектуальную теорию стоимости. Вместе с тем, дальнейших исследований требует разработка методического инструментария, который позволит определить границы фактора интеллектуального капитала в новой созданной стоимости.

Ключевые слова: стоимость; ценность; цена; норма прибавочной стоимости; норма прибыли; интеллектуальный капитал; интеллектуальная теория стоимости. 